\title{
CLINICAL PRESENTATION AND BACTERIOLOGICAL STUDY OF DEEP NECK SPACE ABSCESS
}

\author{
Sheila Raman Kutty1, Balakrishnan², Swathy Jaya Chandran³, Latha Mary4 \\ ${ }^{1}$ Associate Professor, Department of ENT, Academy of Medical Sciences, Pariyaram, Kannur, Kerala. \\ 2 Professor, Department of ENT, Academy of Medical Sciences, Pariyaram, Kannur, Kerala. \\ ${ }^{3}$ Resident, Department of ENT, Academy of Medical Sciences, Pariyaram, Kannur, Kerala. \\ ${ }^{4}$ Senior Resident, Department of ENT, Academy of Medical Sciences, Pariyaram, Kannur, Kerala.
}

\section{ABSTRACT}

\section{BACKGROUND}

Objectives- To study the clinical presentation, aetiology, bacteriology, antibiotic sensitivity and management options of 50 cases of deep neck space infections.

Study Design- Hospital based Prospective, descriptive study.

\section{MATERIALS AND METHODS}

50 cases of deep neck infections admitted in Academy of medical Sciences, Pariyaram, Kannur, India between February 2014 to August 2015 with deep neck space infections were include in the study. Pus was sent for culture and sensitivity analysis. Clinical and microbiological assessments were analysed.

\section{RESULTS}

The most common space involved was the Submandibular space (32\%) in our set up followed by Peritonsillar abscess (28\%), Ludwig's Angina (18\%), Retropharyngeal abscess (8\%), Parotid space (6\%) and Parapharyngeal abscess (4\%). The most common organism isolated was Staphylococcus aureus (24\%), followed by Beta haemolytic streptococci (16\%). Most of the organisms isolated were sensitive to cephalosporins, gentamicin and ciprofloxacin. 2 isolates among Staphylococci (16.6\%) were Methicillin resistant (MRSA). MRSA should be considered as a potential pathogen in deep neck space abscesses. The main morbidity was airway obstruction in $2(4 \%)$ patients and required tracheostomy.

\section{CONCLUSION}

There is an increase in the isolation of methicillin resistant staphylococcus aureus (MRSA) in cases of deep neck infections. Empirical antibiotic treatments must cover gram positive, gram negative and anaerobic pathogens. Early surgical intervention can reduce the complications.

\section{KEYWORDS}

Deep Neck Infection, Peritonsillar Abscess, Submandibular Space Infections, Methicillin Resistant Staphylococcus Aureus.

HOW TO CITE THIS ARTICLE: Kutty SR, Balakrishnan, Chandran SJ, et al. Cilinical presentation and bacteriological study of deep neck space abscess. J. Evolution Med. Dent. Sci. 2017;6(3):193-201, DOI: 10.14260/Jemds/2017/46

\section{BACKGROUND}

The diagnosis and treatment of deep space infections have challenged physicians and surgeons. The complexity of the deep location of these potential spaces make diagnosis and treatment of the infections in these areas difficult. Deep neck space infections affect fascial compartments of the head and neck and their contents. Although the incidence of deep neck space infections was much higher in the pre-antibiotic era, it still continues to be a health problem where it causes significant morbidity and mortality. Compared with infections elsewhere in the body, deep neck infections pose complicated problems, due to numerous portals of entry of infection and proximity to vital structures. The increasing prevalence of patients with immunodeficiency or prior antibiotic treatment may result in unusual clinical

Financial or Other, Competing Interest: None.

Submission 04-12-2016, Peer Review 29-12-2016,

Acceptance 04-01-2017, Published 09-01-2017.

Corresponding Author:

Dr. Sheila Raman Kutty,

\#102, Yamuna Residency,

Near Government Kapikad School,

Kapikad, Mangalore.

E-mail: sheelaent@yahoo.com

DOI: $10.14260 /$ jemds $/ 2017 / 46$

(c) $($ ) $\$$ presentations and pathogens, making the clinical diagnosis and treatment difficult.

Failure to recognise deep space infections early may be due to an altered clinical picture resulting from inappropriate use of antibiotic, increasing. Prevalence of the patients with immunodeficiency and changes in the causes of deep neck space infections and its bacteriology. Before the widespread use of antibiotics, majority of the neck space infections originated in the pharynx and the tonsils. Since the advent of antibiotics, these oropharyngeal infections are no longer a significant aetiology. Dental infections and regional trauma are now common causes of deep neck space infections.

The microbiology of deep neck space infections usually reveals mixed aerobic and anaerobic organisms often with a predominance of oral flora. Both gram positive and gram negative organisms may be cultured. Group A beta haemolytic streptococci species, alpha haemolytic streptococcal species, staphylococcus, Fusobacterium nucleatum, bacteroides, peptostreptococci and Neisseria species are often found together in combination.(1)

Other important considerations include patients who are on chemotherapy or on immunosuppressant drugs for transplantation. These patients may have an increased frequency of deep neck space infections with atypical organisms and they may have more frequent complications.(2) 


\section{MATERIALS AND METHODS}

Hospital based prospective study was conducted in ENT OPD at Academy of Medical Sciences, Pariyaram, Kannur, Kerala, India between February 2014 to August 2015. A total no of 50 patients were studied which included both males and females of all age groups. These patients attended ENT OPD with clinical and radiological evidence of deep neck space infections. Written informed consent for the study was obtained from the patients. Ethical committee clearance was obtained for the study.

Inclusion criteria included patients with complaints of throat pain, neck swelling, trismus, dysphagia, odynophagia, breathing difficulty, change in voice and foreign body sensation in the throat. Exclusion criteria included superficial skin abscesses, abscesses due to infections of the external neck wounds (Surgical or traumatic) and abscesses related to fractures were excluded.

Study tools included a complete ENT, head and neck examination, Radiological examination which included X-ray neck lateral view, Ultrasound Neck and CECT, Pus culture and sensitivity tests. A detailed history, general and clinical examination was done including local examination of the swelling. Routine blood Investigations were done.

Only clinically and radiologically confirmed cases of deep neck space infections of all age groups and both sexes were included in the study. Needle aspiration or incision and drainage was done at the earliest stage in majority of the patients. Pus was sent for culture and sensitivity analysis.

All data was entered into MS, EXCEL then SPSS (Statistical package for social sciences) Version 13 was used to analysis the data. The data thus obtained was analysed statistically and presented in the form of tables, figures and diagrams wherever necessary. Data collected was analysed statistically using descriptive statistical methods like frequencies and percentage. Results were presented in the form of both tables and graphs.

\section{RESULTS}

The study group included 50 patients. All age group were affected by deep neck space infections; maximum number of cases were seen in the age group of 41-50 years. Minimum number of cases were observed in 11-20 years.

Of the 50 patients studied, 32 were males ( $64 \%$ ) and 18 were females (36\%), male preponderance was observed.

The most common presenting symptom was throat pain (98\%), followed by fever (84\%). 70\% patients had neck swelling and $52 \%$ had Odynophagia.

$10(20 \%)$ patients were diabetic on treatment, 6 patients (12\%) had hypertension, 6(12\%) were having COPD, 1 patient (2\%) had HIV and $1(2 \%)$ was HBsAg positive.

Dental infections were the most common cause (16 patients-32\%) followed by tonsillitis (14 patients-28\%), Cause was unknown in 19 (38\%) patients.

The culture was sterile in $15(30 \%)$ patients. Among the cases, the most common organism isolated was staphylococcus aureus (24\%) followed by Beta haemolytic streptococci $(16 \%)$. Most of the organisms isolated were sensitive to cephalosporins, gentamicin and ciprofloxacin. 2 isolates among Staphylococci (16.6\%) were Methicillin resistant (MRSA). MRSA should be considered as a potential pathogen in deep neck space abscesses. In such case a high index of suspicion is needed as well as aggressive treatment including incision and drainage along with culture directed medical therapy has to be started. Antibiotic coverage should include gram negative, gram positive and anaerobic organisms. A combination of third generation cephalosporins and metronidazole are good as empiric antibiotic coverage. MRSA shows resistance to most of the cephalosporins and routine antibiotics while it responds well to vancomycin and Linezolid. Our data also suggest that MRSA infections are on the rise and due consideration should be given to it.

Early surgical intervention was the mainstay of treatment. Empirical antibiotic therapy with cephalosporins and metronidazole was used.

2 patients developed airway obstruction and required tracheostomy and survived with intensive care monitoring.

\section{Results}

\begin{tabular}{|c|c|c|}
\hline Age (in years) & No. of Cases (n= 50) & Percentage (\%) \\
\hline$<10$ Yrs. & 4 & 8 \\
\hline $11-20$ Yrs. & 3 & 6 \\
\hline $21-30$ Yrs. & 5 & 10 \\
\hline $31-40$ Yrs. & 12 & 24 \\
\hline $41-50$ Yrs. & 14 & 28 \\
\hline $51-60$ Yrs. & 7 & 14 \\
\hline$>60$ Yrs. & 5 & 10 \\
\hline \multicolumn{3}{|c|}{ Table 1. Age distribution } \\
\hline
\end{tabular}

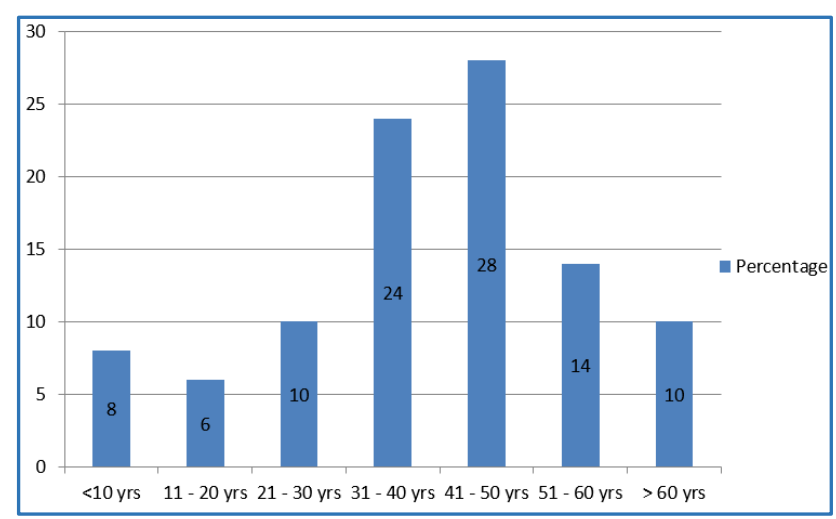

Age in years

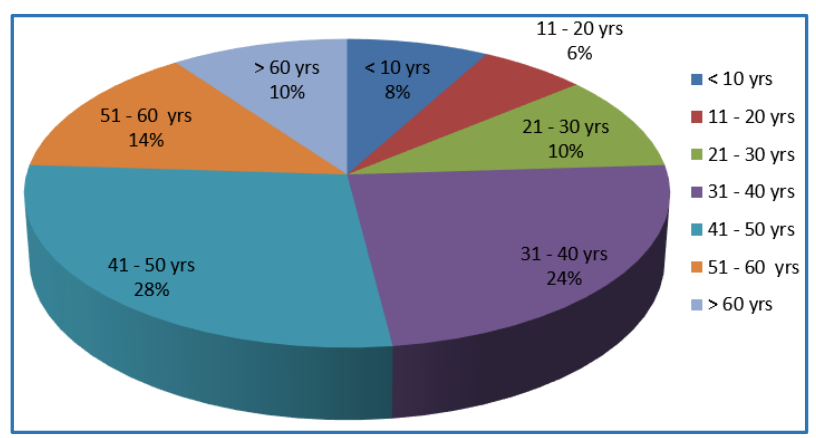

Graph 1. Age distribution of the cases

\begin{tabular}{|c|c|c|}
\hline Gender & No. of Cases & Percentage (\%) \\
\hline Male & 32 & $64 \%$ \\
\hline Female & 18 & $36 \%$ \\
\hline Total & $\mathbf{5 0}$ & $\mathbf{1 0 0} \%$ \\
\hline \multicolumn{2}{|c|}{ Table 2. Sex distribution } \\
\hline
\end{tabular}




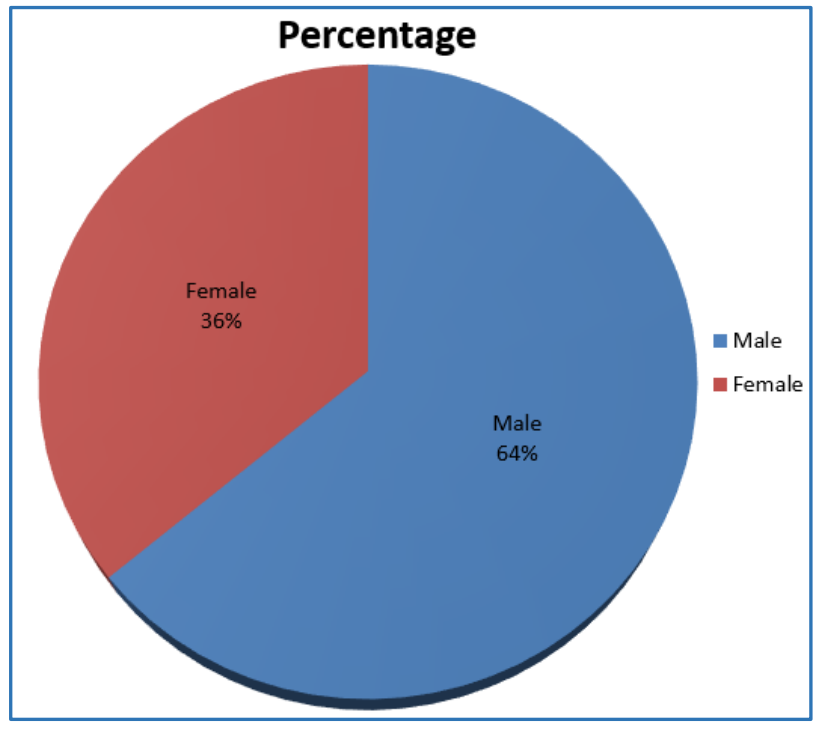

Graph 2. Sex distribuition

\begin{tabular}{|c|c|c|}
\hline $\begin{array}{c}\text { Presenting } \\
\text { Complaints }\end{array}$ & $\begin{array}{c}\text { No. of Patients } \\
\text { (n=50) }\end{array}$ & $\begin{array}{c}\text { Percentage } \\
\text { (\%) }\end{array}$ \\
\hline Pain in the Throat & 49 & 98 \\
\hline Odynophagia & 26 & 52 \\
\hline Fever & 42 & 84 \\
\hline Neck Swelling & 35 & 70 \\
\hline Trismus & 18 & 36 \\
\hline Neck Pain & 20 & 40 \\
\hline Tooth Extraction & 14 & 28 \\
\hline Halitosis & 12 & 24 \\
\hline $\begin{array}{c}\text { Difficulty in } \\
\text { Breathing }\end{array}$ & 2 & 4 \\
\hline \multicolumn{2}{|c|}{ Table 3. Presenting complaints } \\
\hline
\end{tabular}

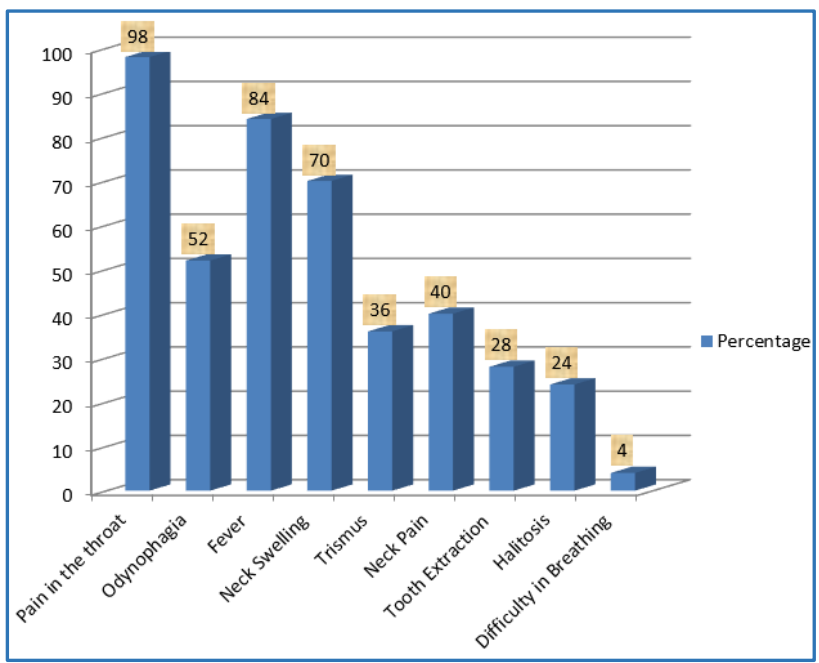

Graph 3. Presenting complaints

\begin{tabular}{|c|c|c|}
\hline $\begin{array}{c}\text { Associated Systemic } \\
\text { Diseases }\end{array}$ & $\begin{array}{c}\text { No. of Patients } \\
(\mathbf{n = 5 0})\end{array}$ & $\begin{array}{c}\text { Percentage } \\
\text { (\%) }\end{array}$ \\
\hline Nil & 31 & 62 \\
\hline Diabetes Mellitus & 10 & 20 \\
\hline $\begin{array}{c}\text { Systemic } \\
\text { Hypertension }\end{array}$ & 6 & 12 \\
\hline COPD & 6 & 12 \\
\hline HBsAg & 1 & 2 \\
\hline HIV & 1 & 2 \\
\hline Table 4. Associated systemic illnesses \\
\hline
\end{tabular}

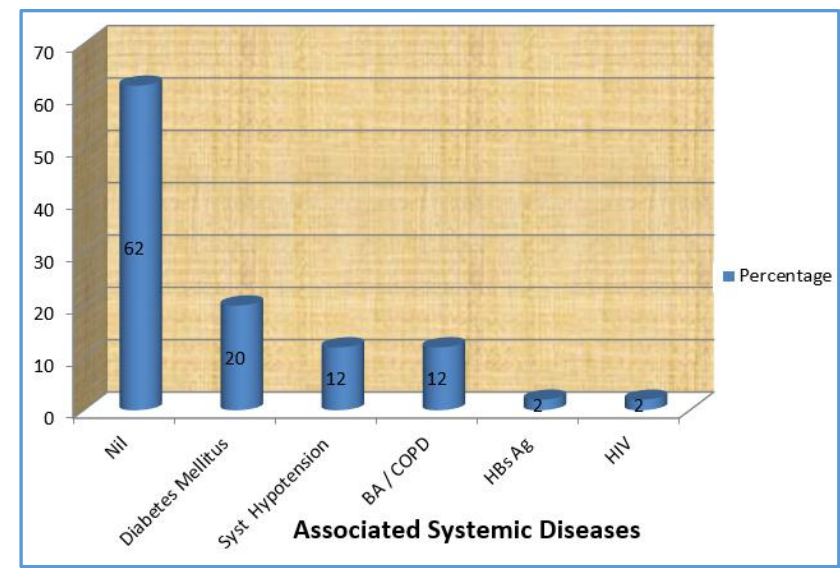

Graph 4. Associated systemic illnesses

\begin{tabular}{|c|c|c|}
\hline Clinical Findings & No. of Patients & Percentage \\
\hline Fever (F) & 44 & 88 \\
\hline Trismus (T) & 23 & 46 \\
\hline Soft Palate Bulge (SPB) & 12 & 24 \\
\hline Tonsillar Enlargement (TE) & 13 & 26 \\
\hline Pus Pointing (PP) & 12 & 24 \\
\hline $\begin{array}{c}\text { Tonsil Pushed Medially } \\
\text { and Downwards (TPMD) }\end{array}$ & 9 & 18 \\
\hline $\begin{array}{c}\text { Jugulodigastric Lymph } \\
\text { Node Enlargement (JDLE) }\end{array}$ & 8 & 16 \\
\hline Uvula Pushed to Right (UPR) & 6 & 12 \\
\hline Uvula Pushed to Left(UPL) & 6 & 12 \\
\hline Poor Orodental Hygiene(POH) & 16 & 32 \\
\hline Floor of Mouth Oedema (FME) & 9 & 18 \\
\hline Neck Swelling (NS) & 35 & 70 \\
\hline Caries Teeth (DC) & 14 & 28 \\
\hline $\begin{array}{c}\text { Lateral Pharyngeal wall } \\
\text { Pushed Medially (LPM) }\end{array}$ & 2 & 4 \\
\hline $\begin{array}{c}\text { Swelling Around the } \\
\text { Mandible (SAM) }\end{array}$ & 3 & 6 \\
\hline $\begin{array}{c}\text { Ear Lobule Pushed } \\
\text { Upwards (ELU) }\end{array}$ & 3 & 6 \\
\hline $\begin{array}{c}\text { Posterior Pharyngeal } \\
\text { Wall Bulge (PPB) }\end{array}$ & 4 & 8 \\
\hline Stridor (STR) & 2 & 6 \\
\hline $\begin{array}{c}\text { Tonalitosis (H) } \\
\text { Medially (TPM) }\end{array}$ & 5 & 6 The 5. Clinical findings \\
\hline
\end{tabular}




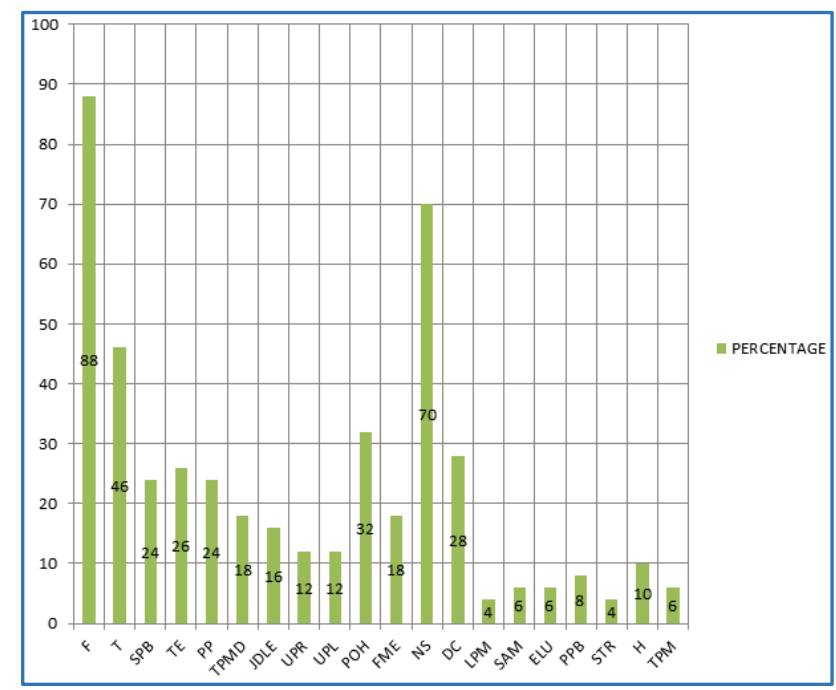

Graph 5. Clinical findings

\begin{tabular}{|c|c|c|}
\hline Etiology & No. of Patients & Percentage \\
\hline Unknown & 17 & 34 \\
\hline Odontogenic & 16 & 32 \\
\hline $\begin{array}{c}\text { Acute } \\
\text { Tonsillitis }\end{array}$ & 8 & 16 \\
\hline $\begin{array}{c}\text { Recurrent } \\
\text { Tonsillitis }\end{array}$ & 6 & 12 \\
\hline $\begin{array}{c}\text { Acute on Chronic } \\
\text { Parotitis }\end{array}$ & 3 & 6 \\
\hline \multicolumn{2}{|c|}{ Total } & $\mathbf{5 0}$ \\
\hline \multicolumn{2}{|c|}{ Table 6. Etiology of neck space infections } \\
\hline
\end{tabular}

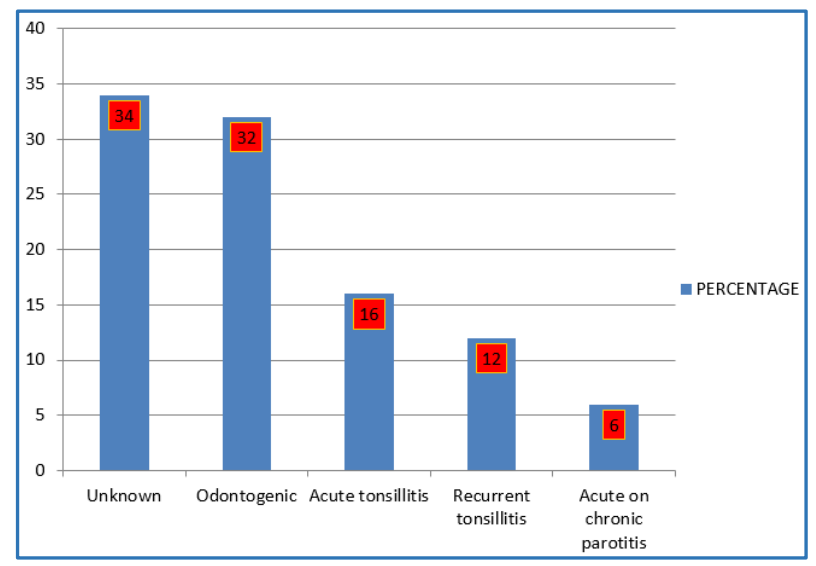

Etiology of neck space infections

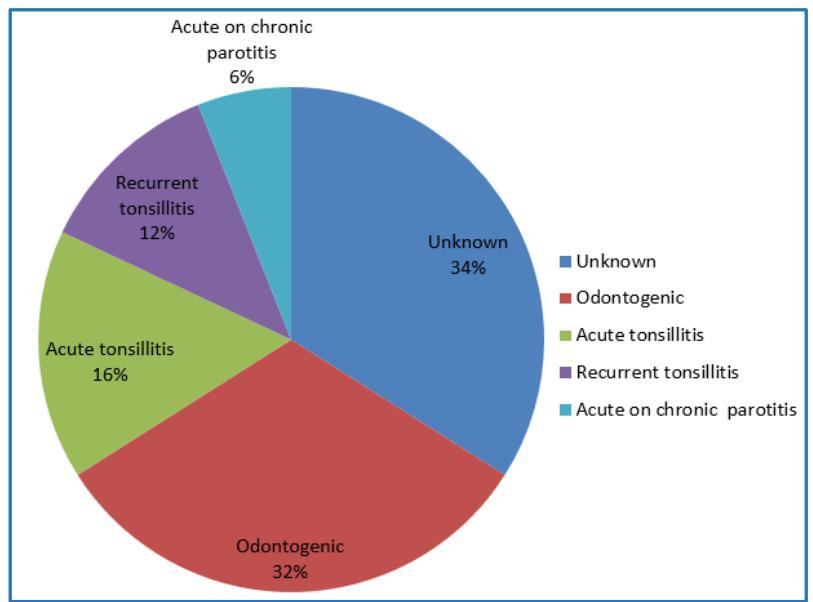

Graph 6. Etiology of neck space infections

\begin{tabular}{|c|c|c|}
\hline Location & No. of Patients & Percentage \\
\hline Submandibular Abscess & 16 & 32 \\
\hline Peritonsillar Abscess & 14 & 28 \\
\hline Ludwig's Angina & 9 & 18 \\
\hline Submental Abscess & 2 & 4 \\
\hline Parotid Abscess & 3 & 6 \\
\hline Retropharyngeal Abscess & 4 & 8 \\
\hline Parapharyngeal Abscess & 2 & 4 \\
\hline Table 7. Anatomic locations of deep neck space infections \\
\hline
\end{tabular}

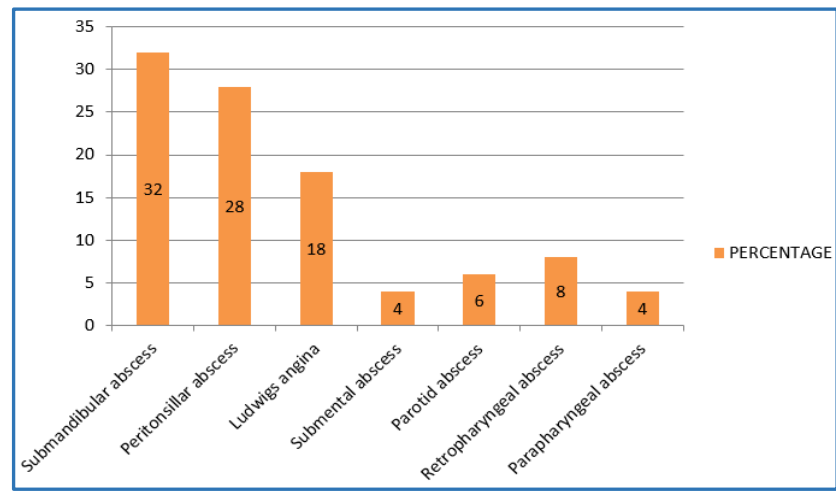

Anatomic Locations

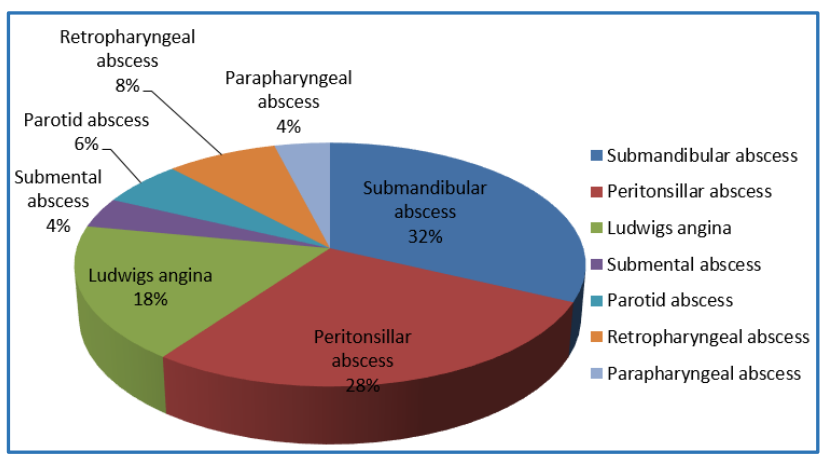

Graph 7. Anatomic locations of deep neck space infections

\begin{tabular}{|c|c|c|}
\hline No. of space involved & No. of patients & Percentage \\
\hline Single space & 48 & 96 \\
\hline Multiple space & 2 & 4 \\
\hline \multicolumn{2}{|c|}{ Table 8. No. of spaces involved } \\
\hline \multicolumn{2}{|c|}{}
\end{tabular}

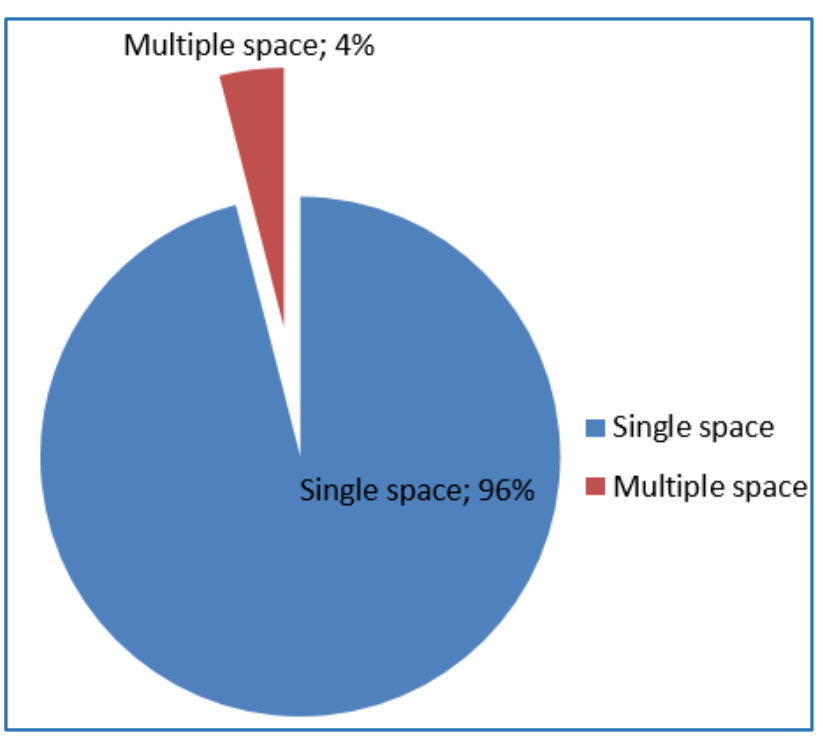

Graph 8. Number of spaces involved 


\begin{tabular}{|c|c|c|}
\hline Diagnosis & No. of Patients & Percentage \\
\hline Clinical & 14 & 28 \\
\hline Radiological & 36 & 72 \\
\hline & 50 & 100 \\
\hline \multicolumn{3}{|c|}{ Table 9. Diagnosis } \\
\hline
\end{tabular}

\begin{tabular}{|c|c|c|}
\hline Organism Isolated & No. of Patients & Percentage \\
\hline Staphylococcus Aureus & 12 & 24 \\
\hline$\beta$-haemolytic Streptococci & 8 & 16 \\
\hline$\alpha$-haemolytic Streptococci & 5 & 10 \\
\hline Pseudomonas & 2 & 4 \\
\hline Klebsiella & 3 & 6 \\
\hline No Growth & 15 & 30 \\
\hline \multicolumn{2}{|c|}{ Table 11. Bacteriology } \\
\hline
\end{tabular}

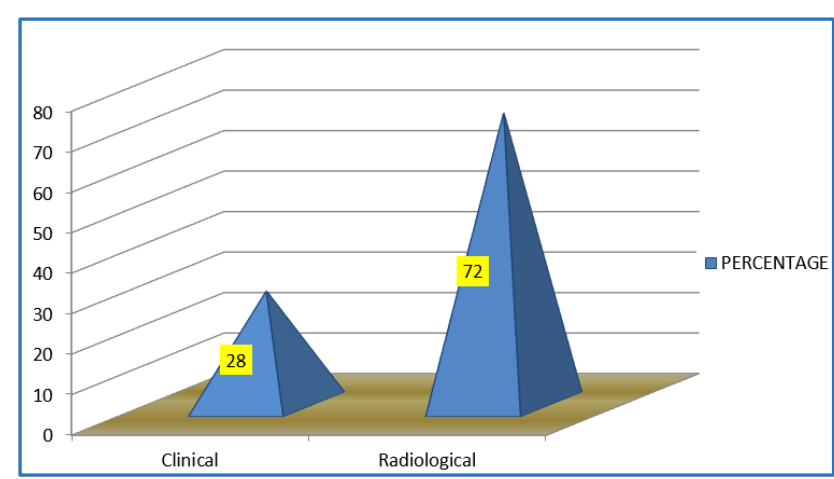

Graph 9. Diagnosis

\begin{tabular}{|c|c|c|}
\hline Treatment & No. of Patients & Percentage \\
\hline I\&D & 31 & 62 \\
\hline Needle Aspiration & 9 & 18 \\
\hline $\begin{array}{c}\text { I\&D and } \\
\text { needle Aspiration }\end{array}$ & 5 & 10 \\
\hline Conservative & 5 & 10 \\
\hline \multicolumn{2}{|c|}{ Table 10. Treatment } \\
\hline
\end{tabular}

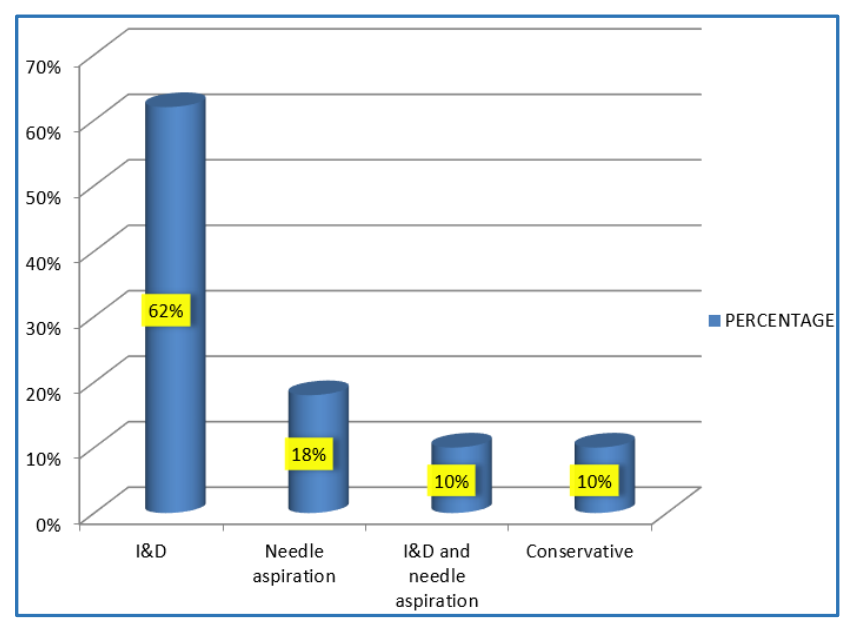

Graph 10. Treatment

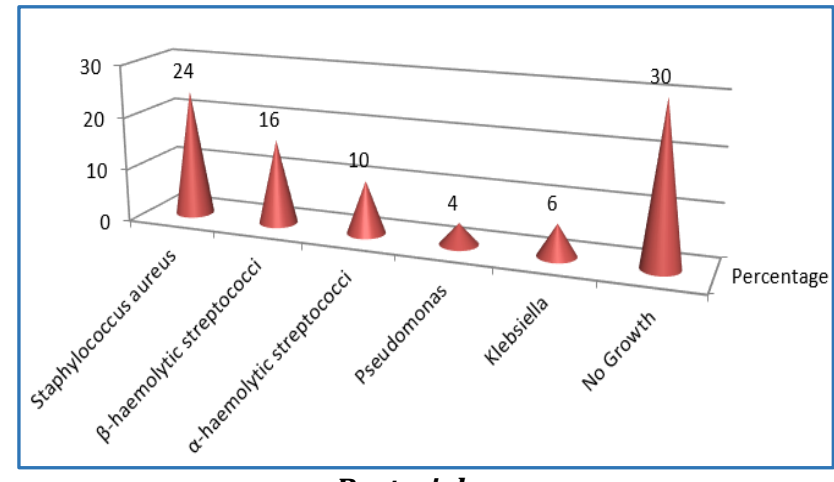

Bacteriology

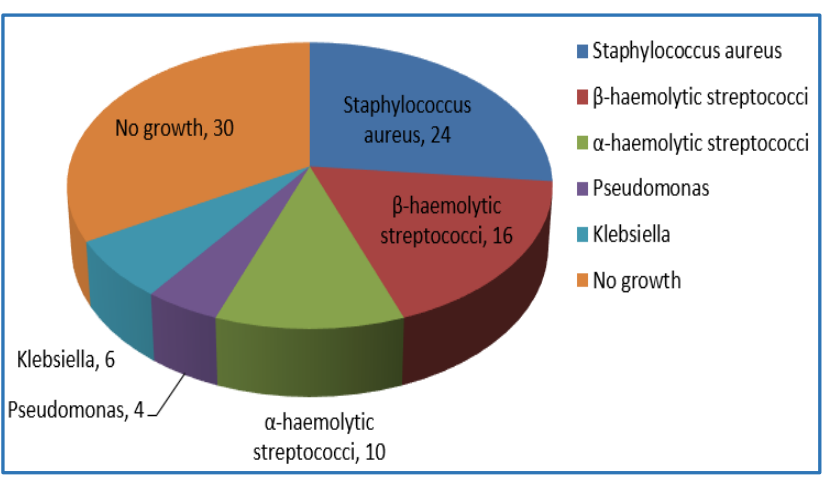

Graph 11. Bacteriology 


\begin{tabular}{|c|c|c|c|c|c|c|c|c|c|c|c|}
\hline 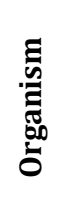 & z & 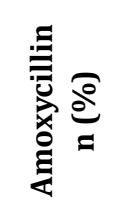 & 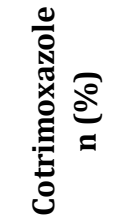 & 胥 & 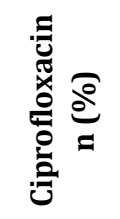 & 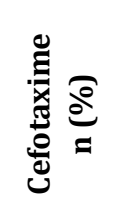 & 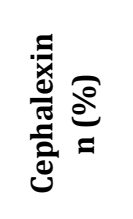 & 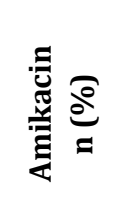 & 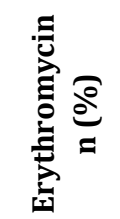 & ఏ & 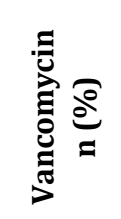 \\
\hline SA & $\begin{array}{c}12 \\
(100) \\
\% \\
(100 \% \\
(100)\end{array}$ & $\begin{array}{c}6 \\
(50 \%)\end{array}$ & $\begin{array}{c}4 \\
(33.3 \%)\end{array}$ & $\begin{array}{c}9 \\
(75 \%)\end{array}$ & $\begin{array}{c}7 \\
(58.3 \%)\end{array}$ & $\begin{array}{c}7 \\
(58.3 \%)\end{array}$ & $\begin{array}{c}7 \\
(58.3 \%) \\
(100)\end{array}$ & $\begin{array}{c}5 \\
(41.6 \%)\end{array}$ & - & $\begin{array}{c}4 \\
(33.3 \%)\end{array}$ & $\begin{array}{c}12 \\
(100 \%)\end{array}$ \\
\hline$\beta \mathrm{HS}$ & $\begin{array}{c}8 \\
(100)\end{array}$ & $\begin{array}{c}1 \\
(12.5 \%) \\
(28.6)\end{array}$ & $\begin{array}{c}0 \\
(0 \%) \\
(57.1) \\
\end{array}$ & $\begin{array}{c}7 \\
(87.5 \%)\end{array}$ & $\begin{array}{c}8 \\
(100 \%) \\
(85.7)\end{array}$ & $\begin{array}{c}4 \\
(50 \%)\end{array}$ & $\begin{array}{c}8 \\
(100 \%) \\
(71.4) \\
\end{array}$ & $\begin{array}{c}4 \\
(50 \%) \\
(71.4) \\
\end{array}$ & - & $\begin{array}{c}4 \\
(50 \%)\end{array}$ & $\begin{array}{c}8 \\
(100 \%)\end{array}$ \\
\hline$\alpha \mathrm{HS}$ & $\begin{array}{c}5 \\
(100 \%)\end{array}$ & $\begin{array}{c}5 \\
(100 \%)\end{array}$ & $\begin{array}{c}0 \\
(0 \%)\end{array}$ & $\begin{array}{c}5 \\
(100 \%)\end{array}$ & $\begin{array}{c}2 \\
(40 \%) \\
(100)\end{array}$ & $\begin{array}{c}5 \\
(100 \%)\end{array}$ & $\begin{array}{c}5 \\
(100 \%) \\
(100)\end{array}$ & $\begin{array}{c}5 \\
(100 \%)\end{array}$ & - & $\begin{array}{c}2 \\
(40 \%)\end{array}$ & $\begin{array}{c}5 \\
(100 \%)\end{array}$ \\
\hline $\mathrm{P}$ & $\begin{array}{c}2 \\
(100)\end{array}$ & $\begin{array}{c}0 \\
(0 \%) \\
(33.3)\end{array}$ & $\begin{array}{c}1 \\
(50 \%)\end{array}$ & - & $\begin{array}{c}2 \\
(100 \%) \\
(100)\end{array}$ & - & $\begin{array}{c}2 \\
(100 \%) \\
(100)\end{array}$ & $\begin{array}{c}2 \\
(100) \\
(66.7)\end{array}$ & $\begin{array}{c}2 \\
(100 \%)\end{array}$ & $\begin{array}{c}2 \\
(100 \%)\end{array}$ & - \\
\hline $\mathrm{K}$ & $\begin{array}{c}3 \\
(100)\end{array}$ & $\begin{array}{c}2 \\
(66.6 \%)\end{array}$ & $\begin{array}{c}2 \\
(66.6 \%)\end{array}$ & - & $\begin{array}{c}2 \\
(66.6 \%) \\
(100)\end{array}$ & - & $\begin{array}{c}2 \\
(66.6 \%) \\
(66.7)\end{array}$ & $\begin{array}{c}2 \\
(66.6)\end{array}$ & $\begin{array}{c}2 \\
(66.6 \%)\end{array}$ & $\begin{array}{c}0 \\
(0 \%)\end{array}$ & - \\
\hline
\end{tabular}

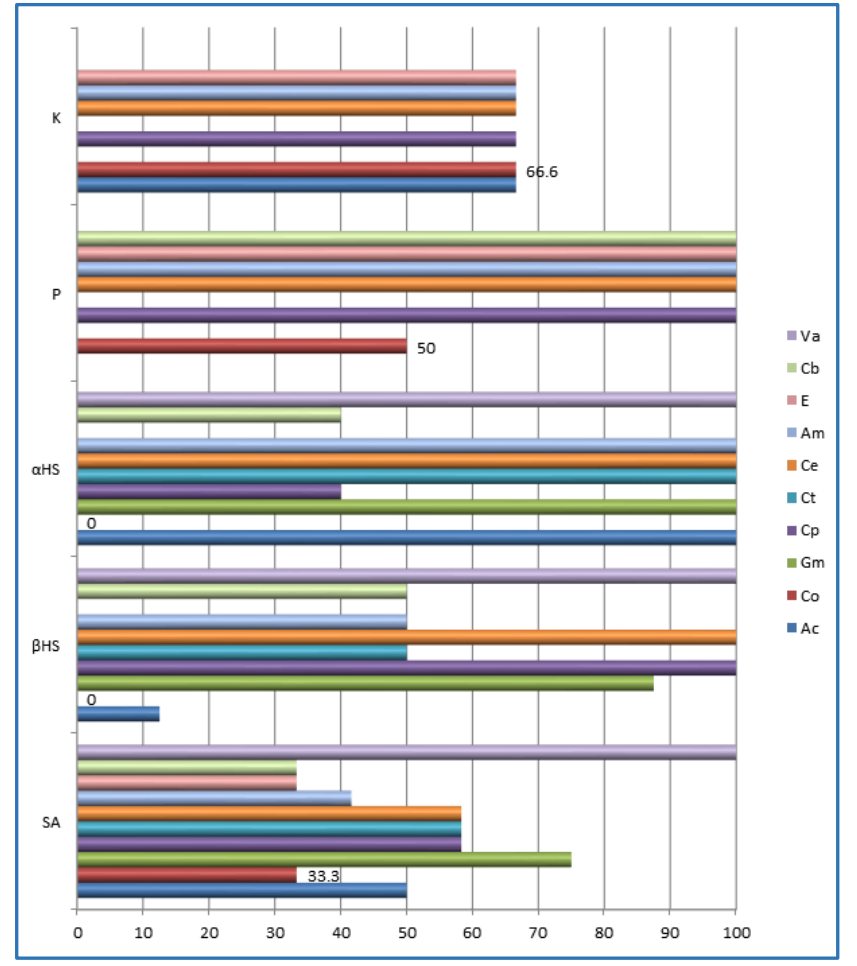

Graph 12. Antibiotic sensitivity pattern

\begin{tabular}{|c|c|c|}
\hline Complications & No. of Patients & Percentage \\
\hline Nil & 48 & 96 \\
\hline $\begin{array}{c}\text { Airway } \\
\text { Obstruction }\end{array}$ & 2 & 4 \\
\hline \multicolumn{2}{|c|}{ Table 13. Complications } \\
\hline
\end{tabular}

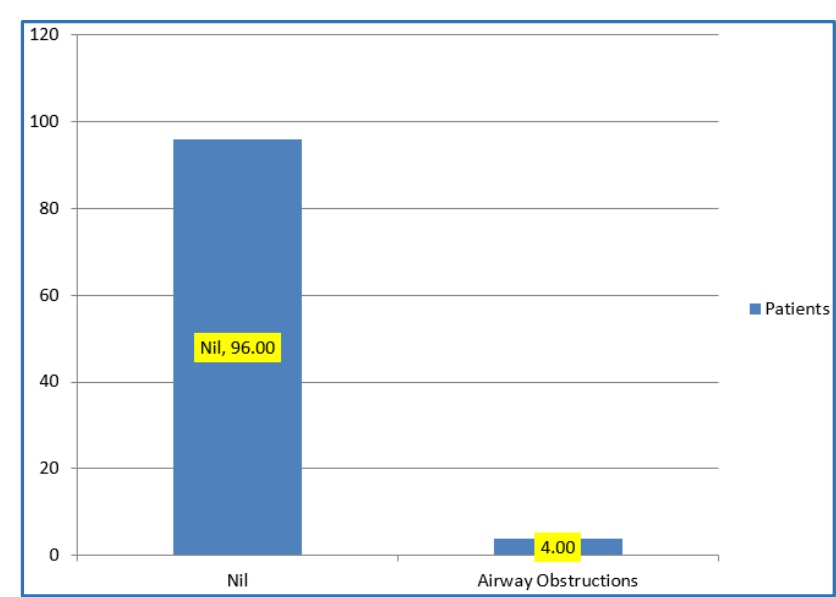

Complications

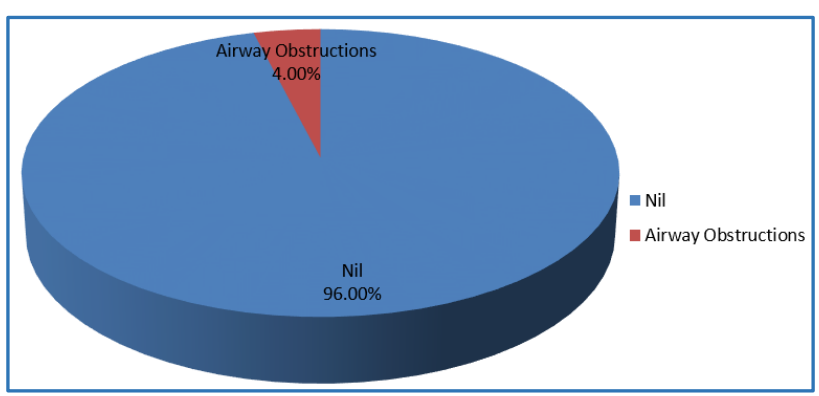

Graph 13. Complications 


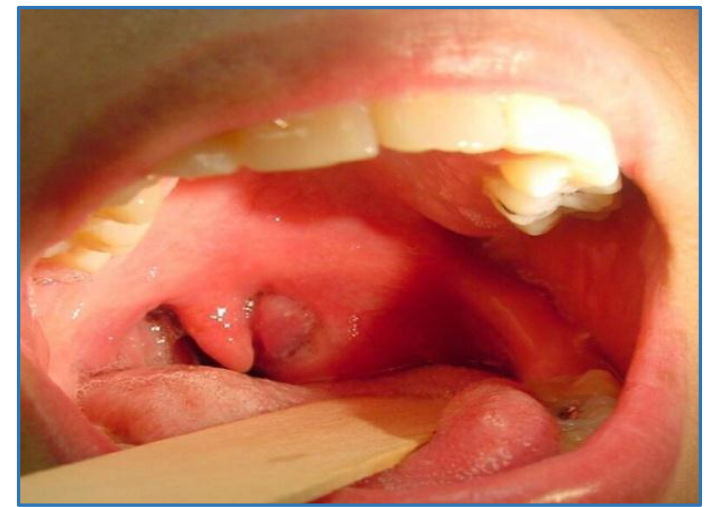

Figure 1. Left peritonsillar abscess

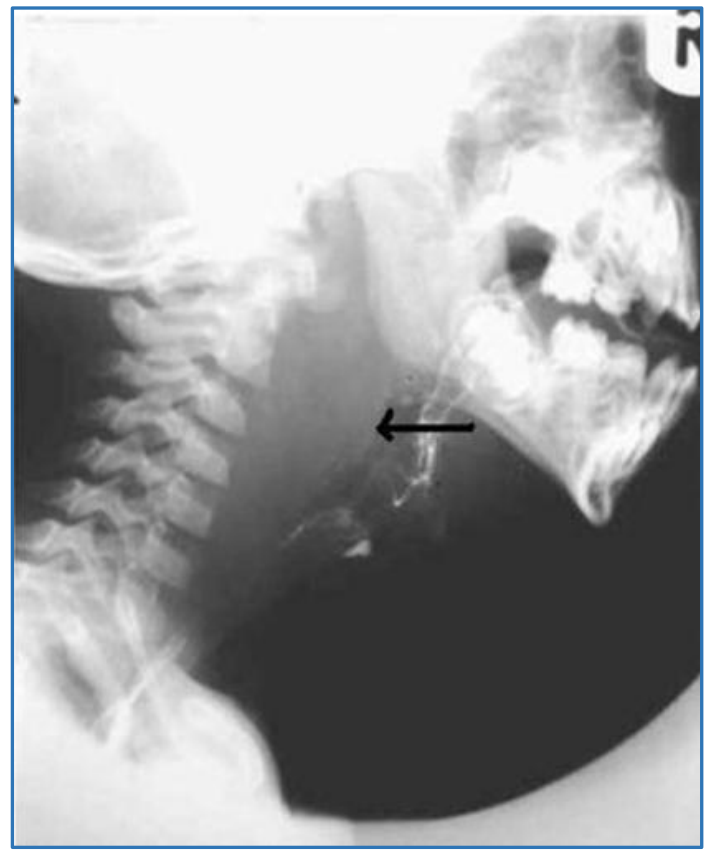

Figure 2 : X-ray lateral view of neck showing retropharyngeal abscess

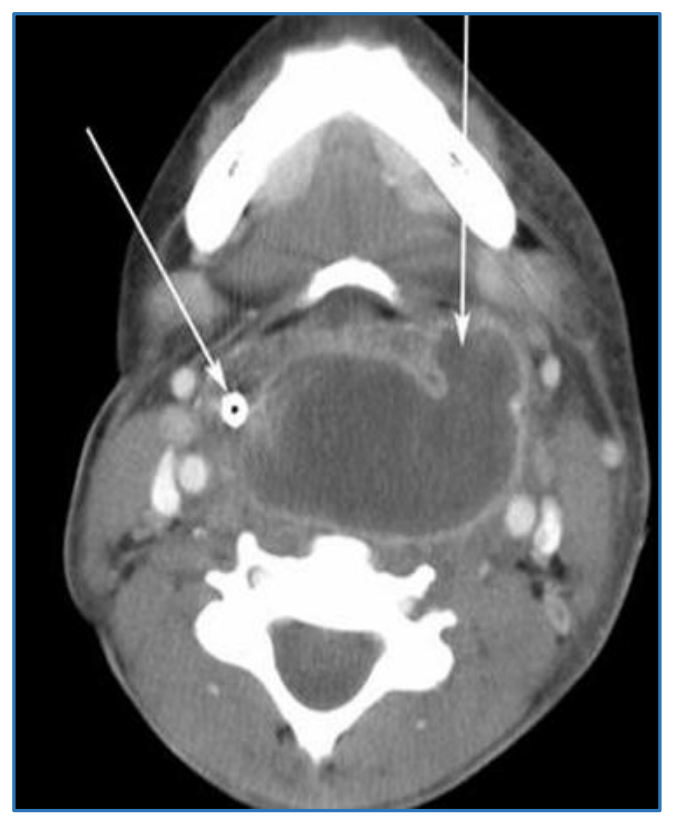

Figure 3. Contrast enhanced CT showing both retropharyngeal and parapharyngeal abscess

\section{DISCUSSION}

Aetiology of deep neck space infections vary depending on the neck space involved. In the pre antibiotic era, $70 \%$ of deep neck infections resulted from spread from pharyngotonsillar infections.(2) In the post antibiotic era, an increasing percentage of infections are odontogenic in origin which often involve the submandibular space and parapharyngeal space.(3) Other causes include salivary gland infections, upper respiratory tract infections, trauma and foreign bodies.(2) Other rare causes are bronchogenic cysts,(4) instrumentation and spread of superficial infections. In addition to classic origins, deep neck space infections are also seen in intra venous drug abusers(5) and hypopharyngeal malignancy.(6) No specific cause may be found in few cases; this may be as high as $50 \%$ as reported by Wright et al.(3) Trauma of the aerodigestive tract by blunt, penetrating or iatrogenic cause is not an uncommon cause of deep neck space infection.

Peritonsillar abscess or cellulitis of streptococcal origin may penetrate the buccopharyngeal fascia directly or extend by retrograde thrombophlebitis to involve the parapharyngeal space. The carotid sheath, which traverses the parapharyngeal space can get involved and provide a pathway of spread to mediastinum. Mosher named this potential avenue of infection the" Lincoln's Highway" of the neck.(2)

In Paediatric population, acute tonsillitis with involvement of the peritonsillar space is the most common cause of deep neck space infections. The second most common source is dental, with involvement of the submandibular space.(2) Retropharyngeal lymph nodes are found in greater number in children and abscess can form secondary to primary focus in the nose, paranasal sinuses, pharynx and middle ear leading to a prevertebral space infection.

Other sources of neck infection are sialadenitis, Bezold's abscess, infections of congenital cysts and fistulas and extension of suppuration in deep cervical lymphatics. (3)

An untreated deep neck space infection spreads within a few days to the surrounding neck spaces, A submandibular neck infection spreads with relative ease to the parapharyngeal space. Then it may spread to the retropharyngeal space. A peritonsillar space infection can also take the same route to the retropharyngeal space. A parapharyngeal abscess can track down into the mediastinum via the "Lincoln's highway", but mediastinal involvement is commoner in a retropharyngeal abscess with its direct access to the superior mediastinum.(2)

Deep neck space infections call for early diagnosis and prompt management. Morbidity in the deep neck space infections is mainly due to mediastinal complication.(7) The other complications which are rarely seen are jugular vein thrombosis, carotid artery rupture and meningitis.(8) The overwhelming complication rate of the past has been reduced with the advent of modern microbiology and haematology, the development of diagnostic tools like CT, MRI and by the effectiveness of modern antibiotics and the development of medical intensive care protocols and surgical techniques.(1)

The clinical picture depends on the spaces affected. They present with a wide range of symptomatology ranging from vague throat pain to severe respiratory embarrassment and dysphagia. Frequently accompanied by systemic toxicity and localised aerodigestive tract compromise and sometimes by 
life threatening squeal like severe airway obstruction, mediastinitis, pericarditis, Jugular vein thrombosis, epidural abscesses and carotid artery erosion. The treating surgeon should have a high index of suspicion in making the diagnosis of deep neck space infections. Clinical examination alone seems to underestimate the extent of disease in $70 \%$ of the cases where appropriate radiological imaging can reveal infections spreading between the spaces. ${ }^{9}$

Before the widespread use of antibiotics, majority of the deep neck space infections originated in the pharynx and the tonsils. Since the advent of antibiotics, these oropharyngeal infections are no longer a significant aetiology. Dental infections and regional trauma are now more common cause of deep neck space infections. Other important considerations include patients who are on chemotherapy or on immunosuppressant drugs.

The microbiology of deep neck space infections usually reveals mixed aerobic and anaerobic organisms often with a predominance of oral flora. Both gram positive and gram negative organisms may be cultured. Group A beta haemolytic streptococci species, alpha haemolytic streptococcal species, staphylococcus aureus, fusobacterium nucleatum, bacteroides, peptostreptococci and Neisseria species are often found together in various combinations. ${ }^{1}$

The management protocols of these infections have not been well defined and are often challenging due to proximity to vital structures and its extension. Decision making between only medical management Vs surgical and medical management are very important in dealing with the deep neck space infections. Surgical drainage is indicated as an early procedure in the presence of any suppurative infection of the neck.

In this study culture was negative in 15 cases (30\%), it may be because of improper use of antibiotics prior to presenting to our centre. Staphylococcus aureus (24\%) was the was the commonest organism isolated, followed by Beta haemolytic streptococci (16\%) and Alpha haemolytic streptococci (10\%). 2(16.6\%) were Methicillin resistant (MRSA). MRSA should be considered as a MRSA should be considered as a potential pathogen in deep neck space abscesses. A high index of suspicion is needed as well as aggressive treatment including I \&D along with culture directed medical therapy.

The increasing isolation of community acquired MRSA (CAMRSA) in head and neck abscesses has been a major focus of current literature. Studies by Ahmmed Shoukath et al revealed MRSA was the most common bacteria isolated and was seen in $50 \%$ of the culture positive patients and $40 \%$ of overall patients. Our data support the notion that MRSA infection are on the rise and due consideration should be given to it. Cultures are critical to determine the organism and its possible resistance patterns. Empirical antibiotics should cover gram positive especially MRSA, gram negatives and anaerobes. This study correlates with that of Ravi Meher studies which shows culture negative in majority of their cases. Commonest organism isolated in their study is also staphylococcus aureus.(10)

Needle aspiration is the most commonly used treatment for peritonsillar abscess now as it is relatively pain free, less cumbersome procedure, not associated with any significant complications and is economical.(11) Majority of remaining cases were managed by incision and drainage i.e., surgical management was preferred to medical management. In this study, early surgical intervention was the mainstay of treatment.

Ravi Meher in their studies recommended early incision and drainage as the standard treatment of choice for all deep neck infections.(10)

In the study by DS Sethi, $19 \%$ of patients developed complications, 6 developed necrotizing cervical fasciitis. One had aspiration pneumonia, two developed acute myocardial infarction, four patients developed septicaemia and multiorgan failure. Mortality rate was $8 \%$.(2) In this study 2 patients developed airway obstruction and underwent emergency tracheostomy and treated aggressively with broad spectrum antibiotics under intensive care unit and survived. There was no mortality. Securing and maintaining an adequate airway must be the first priority.

Appropriate radiologic imaging can reveal infection spreading between spaces, which may not be clinically apparent Contrast enhanced CT is currently considered the radiologic investigation of choice in deep neck infections.

In cases where parapharyngeal and retropharyngeal abscess are suspected CECT not only helps in diagnosis but also helps in identifying impending airway complications before they are clinically detectable, thereby reducing the complications.

Miller et al have concluded in their study that CECT has a high sensitivity and low specificity, which may lead to needless surgery for some patients if used in isolation. Clinical examination and CECT together are the most accurate test to determine the extent of Deep Neck infection.(12)

\section{CONCLUSION}

Despite the wide spread use of antibiotics, deep neck space infections continue to occur and causes great morbidity to the patient. Early presentation of the patients to the hospital, has led to a decrease in the morbidity and mortality. CECT is essential in appropriate management of deep neck infections especially in those involving parapharyngeal and retropharyngeal spaces.

Submandibular abscess is the commonest deep neck infection $(32 \%)$ in our set up followed by peritonsillar abscess (28\%), Ludwig's angina (18\%), Retropharyngeal abscess (8\%), Parotid abscess (6\%) and Parapharyngeal abscess (4\%).

Securing and maintaining an adequate airway must be the first priority endotracheal intubation or tracheostomy is done as per the requirement of the case.

Staphylococcus aureus (24\%) was the commonest organism isolated, followed by Beta haemolytic streptococci (16\%) and Alpha haemolytic streptococci $(10 \%)$. Polymicrobial infections were diagnosed in 2 cases. (4\%). Out of 12 cases of Staphylococcus aureus, 2 (16.6\%) were Methicillin resistant (MRSA). MRSA should be considered as a potential pathogen in deep neck space abscesses.

A high index of suspicion is needed as well as aggressive treatment including incision and drainage along with culture directed medical therapy.

Antibiotic coverage should include gram negative, gram positive and anaerobic micro-organisms. A combination of third generation cephalosporins and 
metronidazole are good as empiric antibiotic coverage. MRSA shows resistance to most of the cephalosporins and routine antibiotics while it responds well to Vancomycin and Linezolid. Our data support the notion that MRSA infection are on the rise and due consideration should be given to it.

Submandibular abscesses are managed by incision and drainage and culture directed medical therapy. Needle aspiration in the treatment of peritonsillar abscess is successful and cost effective. Needle aspiration and I\&D have similar efficacy rates.

The complications of deep neck infection although less common now are still present and are higher in those with diabetes and immunocompromised states requiring aggressive management. Complications include mediastinitis, necrotising cervical fasciitis, septicaemia, multi-organ failure and airway obstruction.

\section{REFERENCES}

[1] Marioni G, Staffieri A, Parisi S, et al. Rational diagnostic and therapeutic management of deep neck infections: analysis of 233 consecutive cases. Ann Otol Rhinol Laryngol 2010;119(3):181-7.

[2] Scott BA, Stienberg CM, Driscoll BP. Deep neck space infections. In: Bailey BJ, Pillsbury HC, Brain P, et al. Head and neck surgery-otolaryngology. $2^{\text {nd }}$ edn. Lippincott-Raven 1998:819-35.

[3] Shumrick KA, Sheft SA. Deep neck infections. In: Paparella MM, Shumrick DA, Gluckman J, et al, eds. Otolaryngology. $3^{\text {rd }}$ edn. Vol. 3. WB Saunders Company 1991;2545-63.
[4] Virolainen E, Haapniemi J, Aitasalo K, et al. Deep neck Infections. Int J Oral Surg 1979;8(6):407-11.

[5] Schondorf J, Jungehülsing $M$, Brochhagen $H G$, et al. Infections of deep soft tissues of the neck in intravenous drug abuse. Laryngorhinootologie 2000;79(3):171-3.

[6] Wong YK, Novotny GM. Retropharyngeal space-a review of anatomy pathology and clinical presentation. J Otolaryngol 1978;7(6):528-36.

[7] Kamath P, Shetty A, Hedge MC. Presentation and management of deep neck space abscess. Indian J of Otolaryngol and Head and Neck Surg 2003;55(4):270-5.

[8] Gidley PW, Ghorayeb BY, Steinberg CM. Contemporary management of deep neck space infections. Otolaryngol Head Neck Surg 1997;116(1):16-22.

[9] Sethi DS, Stanley RE. Deep neck abscesses-changing trends. J Laryngol Otol 1994;108(2):13843.

[10] Parhiscar A, Har-El G, Meher R. Deep neck abscess: a retrospective review of 210 cases. Annals of Otology Rhinology Laryngology 2001;110(11):1051-4.

[11] Otasowie D, Benjamin I, Corneliu A. Management of neck space infections retrospective study of 70 patients. Niger Med Journal 2012;53:12-15.

[12] Nagy M, Backstrom J, Miller. Comparison of the sensitivity of lateral neck radiographs and computed tomography scanning in paediatric deepneck infections. The Laryngoscope 1999;109(5):775-9. 